\title{
Constructing a Regional
}

\section{Identity: The Christian Social}

\section{Union and Bavaria's Common}

\section{Heritage, I949-I962}

\author{
GR A H A F O R D
}

\begin{abstract}
The Christian Social Union's domination of Bavarian state and society is such that it has justifiably been described as Bavaria's 'official and hegemonic party' (Staats- und Hegemonialpartei). However, it is important not to take the CSU's regional identity as an historical given. This article examines how the CSU set about constructing an integral Bavarian (gesamtbayerisch) identity during the 1950 s and early 1960 s by articulating the diverse historical experiences of the region-state's localities and sub-regions as a common Bavarian heritage. Drawing on articles about Bavarian cities, reports on historical re-enactments and commemorative speeches by party leaders, the article explores the celebration of this heritage in terms of 'political character', culture and Christianity.
\end{abstract}

In his posthumously published memoirs Franz Josef Strauss, the former Bavarian minister-president, asserted that 'there is no doubt whatsoever about the CSU's Bavarian identity'. Indeed, according to Strauss, the party's 'unique position, rooted in Bavarian history and tradition, rests, politically speaking, on three pillars', the third of which was 'the CSU's identification with Bavaria'. ${ }^{1}$ Few would disagree.

School of Arts and Media, University of Teesside, Middlesbrough, TS I 3 BA, United Kingdom; G.Ford@tees.ac.uk. I should like to thank the staff of the Archiv für Christlich-Soziale Politik at the Hanns-Seidel-Stiftung for their endeavours in helping me locate material for this article. I should also like to thank Barry Doyle and the journal's anonymous readers for their constructive comments on an earlier version of this paper. But my biggest debts of gratitude are to Nigel Copsey, Linda Polley and Margaret Hems.

1 Franz Josef Strauss, Die Erinnerungen (Berlin: Siedler, I989), 544, 530. All translations of quotations from untranslated sources are by the author. 
Established in the aftermath of the Second World War, the Bavarian Christian Social Union (CSU) is, like its sister party, the Christian Democratic Union (CDU), an interdenominational Christian Democratic party. But whereas the CDU occupies the centre-right throughout Germany with the exception of Bavaria, this role is reserved for the CSU in Bavaria. Here, the CSU has governed for all but three years (I954-7) since I946 and has been the sole party of government since I966. It has polled more than 50 per cent of the vote in every Bavarian regional parliamentary election since I 970 and managed the same feat in federal parliamentary elections between I957 and

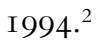

Indeed, such has been the CSU's domination of Bavarian politics that it is difficult to disentangle the party from the state. The CSU deliberately encourages this elision, having appropriated many of the symbols of the Bavarian state for its own party-political purposes. Alf Mintzel's description of the CSU as Bavaria's 'official and hegemonic party' (Staats- und Hegemonialpartei) is therefore perfectly apt. ${ }^{3}$ This symbiotic relationship between party and region means that the CSU can be characterised as a regionalist party; and while it is not, strictly speaking, an ethno-regionalist party, it nevertheless shares some traits with such organisations. The CSU's identification with Bavaria is therefore comparable with, for example, that of Convergence and Unity ( $\mathrm{CiU}$ ) with Catalonia, the Scottish National Party (SNP) with Scotland and even Italy's Lega Nord (LN) with 'Padania'. ${ }^{4}$ Moreover, while these parties construct their regions as historic nations and seek to mobilise support through a nationalist discourse, the CSU deploys similar devices in emphasising Bavaria's historic statehood and in using the emotive language of Heimat (literally, 'homeland'). ${ }^{5}$

Yet the CSU is more than simply a regionalist party; it is also a federal party insofar as it plays an active role on the national political stage. The CSU's position in federal politics is framed by two overriding objectives, both of which form part of Bavaria's state tradition reaching back into the early nineteenth century: the protection and furtherance of Bavarian statehood and the Bavarian state's right to consultation and participation in German and European affairs. ${ }^{6}$ The CSU pursues these objectives through a number of institutional arrangements: its control of the Bavarian state government allows it to exercise influence through the Bundesrat (the federal regional chamber of the West German parliament) and other intergovernmental bodies, such as the regular conferences of minister-presidents. ${ }^{7}$ At the same time, the CSU regional group (Landesgruppe) in the Bundestag (the federal parliament) has

2 Alf Mintzel, Die CSU-Hegemonie in Bayern: Strategie und Erfolg; Gewinner und Verlierer (Passau: Wissenschaftsverlag Richard Rothe, I998), 30, 3I, tables 2 and 3.

3 Ibid., 27.

${ }^{4}$ For ethno-regionalist parties, see Lieven De Winter and Huri Türsan, eds., Regionalist Parties in Western Europe (London and New York: Routledge, I998).

5 Claire Sutherland, 'Nation, Heimat, Vaterland: The Reinvention of Concepts by the Bavarian CSU', German Politics, I0, 3 (2003), I3-36.

6 Mintzel, CSU-Hegemonie, 92.

7 Andreas Kiessling, Die CSU: Machterhalt und Machterneuerung (Wiesbaden: VS Verlag für Sozialwissenschaften, 2004), I3 I; Uwe Leonardy, 'The Institutional Structures of German Federalism', 
been able to exercise disproportionate influence through its parliamentary alliance (Fraktionsgemeinschaft) with the CDU. In particular, the CSU's participation in federal governments in I949-69, I982-98 and since 2005 has enabled the party to advance Bavarian regionalist interests while simultaneously shaping German and European

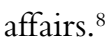

The CSU thus performs a dual role as both a regionalist and a federal party. ${ }^{9}$ As a regionalist party its political legitimacy resides primarily in its identification with the Bavarian state. But it uses this identification - underpinned by the party's regional electoral dominance - to project itself on to the German political stage. For the CSU representing the regionalist interest is therefore compatible with a national political vocation. It is this national dimension that distinguishes the CSU from ethno-regionalist parties, for it neither constructs Bavaria as a nation in its own right nor eschews the German national state. ${ }^{10}$ The CSU can therefore legitimately claim to be both a Bavarian and a German party. ${ }^{11}$ Yet just as Mintzel has been at pains to emphasise that the CSU's hegemony was not foreordained,,$^{12}$ so it is equally important not to take the party's regional identity - its identification with Bavaria and its understanding of Bavaria's relationship with the nation - as an historical given. While the CSU has always identified itself with the territorial and institutional integrity of the Bavarian state, its early years were characterised by bitter internal disputes between liberal conservatives and clerical conservatives over different conceptions of the party, of Bavaria and of Bavaria's place within a future German national state. ${ }^{13}$

This article seeks to trace an aspect of these debates that has so far not received adequate scholarly attention. Scholars of the CSU recognise that the party forged a Bavarian identity that combined a 'liberal' commitment to modernisation and the nation with a 'conservative' belief in tradition and the region, mediated through moderate federalism - an identity that made possible the CSU's attempts gradually to elide party and state from the mid-I950s onwards. ${ }^{14}$ Yet while political scientists and historians have done much to explore the CSU's organisation, federalism,

in Charlie Jeffrey, ed., Recasting German Federalism: The Legacies of Unification (London and New York: Pinter, I999), 3-22.

${ }^{8}$ For the CSU regional group, see Kiessling, CSU, I 34-46; Petra Weber, 'Föderalismus und Lobbyismus. Die CSU-Landesgruppe zwischen Bundes- und Landespolitik I949 bis I969', in Thomas Schlemmer and Hans Woller, eds., Bayern im Bund. Band 3: Politik und Kultur im föderativen Staat 1949 bis 1973 (Munich: Oldenbourg, 2004), 23-II6.

9 The term 'dual role' is Mintzel's. Mintzel, CSU-Hegemonie, 92.

${ }^{10}$ Cf. Sutherland, 'Nation, Heimat, Vaterland', 2 I-2, who nevertheless argues that conceptually the CSU is a 'contemporary nationalist party' with regard to Bavaria.

11 Albrecht Mintzel, 'The Christian Democracy in the Federal Republic of Germany', in Mario Caciagli et al., eds., DC: Christian Democracy in Europe (Barcelona: Institut de Ciències Politiques i Sociales, I992), 55-82, at 72 .

12 Mintzel, CSU-Hegemonie, 28.

13 Thomas Schlemmer, Aufbruch, Krise und Erneuerung: Die Christlich-Soziale Union 1945 bis 1955 (Munich: Oldenbourg, I998).

14 Mintzel, CSU-Hegemonie, 46; Mark S. Milosch, Modernizing Bavaria: The Politics of Franz Josef Strauß and the CSU, 1949-1969 (New York and Oxford: Berghahn, 2006), 5I; Thomas Schlemmer, 'Zwischen Tradition und Traditionsbildung: Die CSU auf dem Weg zur Hegemonialpartei I945 bis I976', Mitteilungsblatt des Instituts für soziale Bewegungen, 24 (2000), I59-80, esp. I6I, I70, I77. 
ideology, industrial modernisation policies and discourse, less attention has been paid to the CSU's identification with Bavaria as a place. ${ }^{15}$ And despite important new insights, the same is generally true of recent interest in postwar Bavarian identity. Without exaggerating the threat to Bavarian territorial integrity, historians have nonetheless highlighted intra-Bavarian tensions, manifested at their most extreme in 'separatist' demands in Swabia and Franconia. The focus of this research has consequently been on the construction of Bavarian 'state consciousness', an approach that has concentrated primarily on the symbols and institutions of statehood - the constitution, flag, coat of arms, anthem, order of merit and the role of the ministerpresident - as well as the 'politics of history', such as museums, exhibitions and historical associations. ${ }^{16}$ The CSU was certainly instrumental in this process of state building, but not exclusively so. More importantly, these studies do not consider how the CSU constructed, understood and identified with Bavaria as a place.

Drawing primarily on the speeches of party leaders Hans Ehard and Hanns Seidel, along with the party newspaper, the Bayern-Kurier, this article explores how an integral Bavarian (gesamtbayerisch) identity was being constructed between I949 and I962. This is not to suggest that there was a direct causal link between the CSU's regional identity and its gradual electoral conquest of Bavaria. Nevertheless, an integral Bavarian identity was essential if the CSU was to become a truly interdenominational party and therefore the 'official party' of Bavarian state and society. ${ }^{17}$ The years between I949 and 1962 were decisive in this development. Prior to I949, the issue of the CSU's regional identity was subsumed by disagreements over Bavaria's relationship with a future German national state. The establishment of the Federal Republic changed the political parameters, for the CSU had now to accommodate itself to the new - if only partial - national state, while also being locked in a fratricidal struggle with a regionalist rival, the Bavarian Party (Bayernpartei or BP). By the early I960s, however, the CSU had all but vanquished the BP and had asserted itself as the dominant political force in Bavaria. Moreover, the early I96os can be considered a watershed in both Bavarian and West German politics, as Hanns Seidel died in I96I, Hans Ehard stepped down as minister-president in I962 and Konrad Adenauer resigned as federal chancellor in I963.

15 Alf Mintzel, Die CSU: Anatomie einer konservativen Partei 1945-1972 (Opladen: Westdeutscher Verlag, I975); Schlemmer, Aufbruch; Karl-Ulrich Gelberg, Hans Ehard: Die föderalistische Politik des bayerischen Ministerpräsidenten 1946-1954 (Düsseldorf: Droste, I992); Aline Marie Kuntz, 'Conservatives in Crisis: The Bavarian Christian Social Union and the Ideology of Antimodernism', Ph.D. thesis, Cornell University, I987; Milosch, Modernizing Bavaria; Sutherland, 'Nation, Heimat, Vaterland'.

16 Ulrike Stoll, 'Bayern - ein Land ohne Identitätsprobleme?', Geschichte im Westen, I6, I (200I), 20-37; Ulla-Britta Vollhardt, 'Zwischen Staatstradition und Regionalbewußtsein: Staatliche Heimatpolitik in Bayern nach I945', in Habbo Knoch, ed., Das Erbe der Provinz: Heimatkultur und Geschichtspolitik nach 1945 (Göttingen: Wallstein Verlag, 200I), I I7-42; Karl-Ulrich Gelberg, 'Staatsbewusstsein und Föderalismus in Bayern nach I945', Politische Studien, 392 (2003), 64-78; Thomas Mergel, 'Staatlichkeit und Landesbewußtsein: Politische Symbole und Staatsrepräsentation in Bayern und Nordrhein-Westfalen I945 bis I975', in Schlemmer and Woller, Politik und Kultur, 28I-347; Edgar Wolfrum, 'Geschichtspolitik in Bayern: Traditionsvermittlung, Vergangenheitsbearbeitung und populäres Geschichtsbewußtsein nach I945’, in ibid., 349-409.

17 Schlemmer, 'Tradition', I6I. 
Ehard and Seidel were the CSU's most important regional politicians during this period: Ehard as party chairman (I949-55) and minister-president (I946-54 and I960-62), Seidel as party chairman (I955-6I), minister of economics (I947-54) and minister-president (I957-60). Although Ehard was generally more sympathetic to the CSU's clerical-conservative wing, he was not a 'party man' as such. Rather, he identified first and foremost with the Bavarian state, his conception of which appears to have been shaped by his background as a Franconian and career civil servant, not to mention his marriage to a Protestant. Hence, while the CSU's organisation deteriorated under his leadership, as a well-respected minister-president he is credited with having held the party together. In particular, he can be considered as one of the architects of the party's 'moderate federalism'. ${ }^{18}$ Ehard's articulation of a Bavarian 'state consciousness' can be seen in a similar light as laying the discursive groundwork for the party's reform-minded elements. Chief among these was Ehard's successor: the Franconian Hanns Seidel. Seidel belonged to the CSU's liberal-conservative wing, and it was under his auspices that the party's organisational modernisation was initiated in the mid-I950s. ${ }^{19}$ The Bayern-Kurier was a vehicle for party reformers. It was founded in I950 by Lorenz Sedlmayr - a man whose roots were in the Christian trade union movement and who was a long-time advocate of a Christian people's party ${ }^{20}$ - and by Franz Josef Strauss, both of whom were on the liberal-conservative wing of the party. ${ }^{21}$ Strauss, moreover, had become CSU general secretary in 1948 and was already emerging as the party's most important federal politician.

The principal contention of this article is that, in forging an integral identity, the CSU exploited Bavaria's urban past as a 'political resource', ${ }^{22}$ articulating the diverse historical experiences and traditions of the state's localities and sub-regions as a common Bavarian heritage. As David Lowenthal argues, 'heritage is not history', but rather a celebration of the past; it is 'a profession of faith in a past tailored to present-day purposes'. ${ }^{23}$ In this respect, heritage draws on the past in order to fix identity by reconciling, integrating and synthesising contradictory and conflicting histories. ${ }^{24}$ The emphasis on a local sense of place - in commemorative speeches, reports on historical re-enactments and articles about Bavarian towns and

18 For Ehard, see Gelberg, Hans Ehard.

19 For Seidel, see Hans Ferdinand Gross, Hanns Seidel 1901-1961: Eine politische Biographie (Munich: Archiv für Christlich-Soziale Politik der Hanns-Seidel-Stiftung, I992).

20 Noel D. Cary, The Path to Christian Democracy: German Catholics and the Party System from Windthorst to Adenauer (Cambridge, MA, and London: Harvard University Press, I996), 74-6.

21 For the Bayern-Kurier see Heinz-Dietrich Fischer, Parteien und Presse in Deutschland seit 1945 (Bremen: Schünemann Universitätsverlag, I97I), I59-60, 200-I; Alf Mintzel, Die CSU, I65, 338-42; Gross, Hanns Seidel, I43-4.

22 For heritage as a 'political resource', see G. J. Ashworth and Brian Graham, 'Senses of Place, Senses of Time and Heritage', in G. J. Ashworth and Brian Graham, eds., Senses of Place: Senses of Time (Aldershot: Ashgate, 2005), 3-I2, at 7, 8 .

23 David Lowenthal, The Heritage Crusade and the Spoils of History (Cambridge: Cambridge University Press, I998), $\mathrm{x}$.

24 Ibid., xi. A similar point has been made with regard to 'collective memory' in Alon Confino, The Nation as a Local Metaphor: Württemberg, Imperial Germany, and National Memory, 1871-1918 (Chapel Hill and London: University of North Carolina Press, I997), 8. 
cities - was therefore about much more than fostering local pride. Given that both the region-state and the nation-state are essentially abstract concepts, the local allowed for the articulation of the tangible, which could be presented as both unique and representative at one and the same time. ${ }^{25}$ This article reveals how the celebration of local heritage as such was central to the CSU's regional identity, politically, culturally and spiritually.

\section{The development of party politics in Bavaria since the I860s}

The CSU's regional identity formation was contested. In order to understand why this was the case it is first necessary to sketch out the development of party politics in Bavaria since the late I860s. While a Bavarian territorial entity has existed in some form or other for more than a millennium, the modern state is in fact a product of the Napoleonic Wars, when the Electorate of Bavaria ('Old Bavaria') acquired numerous smaller territories in Swabia and Franconia ('New Bavaria'). ${ }^{26}$ The Bavarian ministerial bureaucracy subsequently set out to forge a unifying 'state consciousness', but in terms of political culture Bavaria remained fragmented in what Mintzel refers to as 'traditional zones': Old Bavaria, Swabia and Franconia, the first two of which were predominantly Catholic, while the latter can be subdivided into Catholic Main-Franconia and a Franconian-Protestant corridor. ${ }^{27}$ Importantly, modern party politics took on somewhat different manifestations in each of these zones, shaped primarily, though by no means solely, by denomination and attitudes to the nation.

Since Bavaria was a predominantly Catholic state, political Catholicism emerged as the dominant force in Bavarian politics from the late 1860 s in the shape of the Patriot Party, which, following its merger with the Centre Party in I 887, became the Bavarian Centre Party. From the beginning, however, Bavarian political Catholicism was inextricably linked with the politics of regionalism. Hence the Patriots initially opposed German unification under Prussian auspices and later sought to defend Bavarian autonomy within the German empire. ${ }^{28}$ Bavarian political Catholicism was by no means homogeneous, however. As Mintzel has pointed out, it was characterised by two basic currents: clerical-conservative and Bavarian-patriotic in Old Bavaria and more German-oriented in Swabia and Main-Franconia. ${ }^{29}$

The Bavarian Centre did not, however, monopolise regionalist politics, for in the mid-I 890 s the Bavarian Peasants' League (BBB) emerged as a particularist, democratic

25 Alon Confino, 'Federalism and the Heimat Idea in Imperial Germany', in Maiken Umbach, ed., German Federalism: Past, Present, Future (Basingstoke: Palgrave, 2002), 70-90, at 78.

26 Peter Claus Hartmann, Bayerns Weg in die Gegenwart: Vom Stammers herzogtum, zum Freistaat heute, 2nd edn (Regensburg: Verlag Friedrich Pustet, 2004), 35 I-6.

27 Mintzel, CSU-Hegemonie, 33-8.

${ }^{28}$ For a good summary see Dieter Albrecht, 'Von der Reichsgründung bis zum Ende des Ersten Weltkrieges (I87I-I9I8)', in Alois Schmid, ed., Handbuch der bayerischen Geschichte. Bd. IV: Das Neue Bayern: Von 1800 bis zur Gegenwart. Erster Teilband: Staat und Politik 2nd edn (Munich: C. H. Beck, 2003), 3 I 8-438, at 336-45.

29 Mintzel, CSU-Hegemonie, 39. 
and anti-clerical rival in the Catholic countryside. ${ }^{30}$ Protestant Franconia, on the other hand, was essentially terra incognita for political Catholicism. Instead it was known for its strong German national orientation, represented above all by the national liberals and social democrats; and these parties also performed well in urban-industrial enclaves throughout the region. ${ }^{31}$ Bavaria therefore lacked an integral political party. ${ }^{32}$

In the aftermath of the First World War, particularist elements in the Bavarian Centre forced its secession from the national party, creating the Bavarian People's Party (BVP) in its stead. The BVP aspired to be both an interconfessional party and the 'official party' of Bavarian state and society. Unlike the CSU after I945, it was neither. This stemmed from the fact that the BVP was in reality a party of political Catholicism and therefore all but unelectable in Protestant Franconia. But even in its Catholic heartlands it was unable to achieve hegemony, since it faced electoral competition from the Peasants' League. Although both the BVP and the CSU presented themselves as the defenders of Bavarian statehood, the substance was different. The CSU became - after its traumatic early years - a party of moderate federalism and an active participant in the construction of a democratic West German state. In particular, the parliamentary alliance with the CDU enabled the CSU to further Bavarian interests while simultaneously accepting national governmental responsibility. The BVP, however, used federalism to challenge the democratic Weimar state in the early I920s and marginalised itself in national politics by ending its parliamentary arrangement with the Centre Party in the Reichstag. Although the BVP later became more conciliatory, it remained a party dominated by the backward-looking particularism of rural and small-town Catholic Old Bavaria..$^{33}$

Following the Second World War Catholic parties throughout western Europe eschewed confessional politics in favour of non-confessional 'Christian' and democratic politics. Although these Christian Democratic parties manifested themselves differently in terms of both time and place, they were characterised by a core commitment to 'Christian values'. Strongly influenced by Catholic social teaching and sharing a suspicion of liberalism and social democracy and a deep hostility to communism, Christian Democratic parties embraced, to a greater or lesser extent, the social market economy, social partnership, European integration and the Atlantic Alliance. ${ }^{34}$ Yet while Christian Democratic parties did not subscribe to confessional politics, most were essentially parties of practising Catholics. In Belgium and the Netherlands, for example, the postwar Christian People's PartySocial Christian Party (CVP-PSC) and Catholic People's Party (KVP) respectively

30 Albrecht, 'Von der Reichsgründung', 350-3.

31 Mintzel, CSU-Hegemonie, 39.

32 Ibid., 39-40.

33 Klaus Schönhoven, Die Bayerische Volkspartei 1924-1932 (Düsseldorf: Droste, I972); D. R. Dorondo, Bavaria and German Federalism: Reich to Republic, 1918-33, 1945-49 (Basingstoke: Macmillan, I992).

34 See David Hanley, 'Introduction: Christian Democracy as a Political Phenomenon', in David Hanley, ed., Christian Democracy in Europe: A Comparative Perspective (London: Pinter, I994), I-I I; Kees van Kersbergen, 'The Distinctiveness of Christian Democracy', in ibid., 3 I-47; Anton Pelinka, 'European Christian Democracy in Comparison', in Michael Gehler and Wolfram Kaiser, eds., Christian Democracy in Europe since 1945 (London and New York: Routledge, 2004), I93-206. 
were initially little more that reincarnations of prewar Catholic parties. ${ }^{35}$ And even the French Mouvement Républicain Populaire (MRP), usually considered to be the archetypal Christian Democratic party of the late I940s and I950s, drew its support predominantly from traditionally conservative 'Christian' regions. ${ }^{36}$

More emphatically than elsewhere in post-Second World War western Europe, the West German CDU and the Bavarian CSU were conceived as interdenominational parties. The aspiration to an interconfessional movement was not new, but it was made possible by the discrediting of Weimar-era conservative nationalism, liberalism and, to a lesser extent, political Catholicism and the trauma of the Third Reich. ${ }^{37}$ That West German Christian Democracy manifested itself in two parties was, however, in part fortuitous. Under Allied occupation between I945 and I949, party formation took place from below, creating as a consequence relatively strong regional associations. But West Germany's region-states (Länder) were largely new entities, with the notable exceptions of Hamburg, Bremen and Bavaria. The CSU's formation was therefore shaped by an existing state tradition and a strong regionalist impulse; and the latter quickly asserted itself against those who envisaged the CSU as a constituent association of a future Christian 'Reich Union'. Hence, while the CSU was willing to cooperate with the CDU, it chose to preserve its autonomy when the CDU regional associations finally established a federal party organisation in I950. ${ }^{38}$ As such, the CDU and CSU constituted two separate and distinct political parties, with the former generally considered to be 'more centrist, more pluralistic, less Catholic and less conservative' than its Bavarian sister party. ${ }^{39}$ Yet despite the immediate postwar hopes invested in Christian Democracy, it took years before the CDU and CSU became truly interconfessional parties..$^{40}$ The internecine struggle between the CSU's liberal-conservative and clerical-conservative wings was in part a battle for the interdenominational soul of the party and, by extension, over whether the CSU would embrace an integral Bavarian identity.

The CSU's liberal-conservative wing was strongest in Franconia, where former members of the liberal and nationalist parties often helped to co-found the party. Its advocates viewed the CSU as an interdenominational party within the emerging Christian Democratic mainstream and favoured a reasonably strong central government within a federal German state. ${ }^{41}$ The clerical-conservative wing, on the

35 Jac Bosmans, 'The Primacy of Domestic Politics: Christian Democracy in the Netherlands', in Gehler and Kaiser, Christian Democracy in Europe, 54-66, at 54-6; Emiel Lamberts, 'The Zenith of Christian Democracy: The Christelijke Volkspartij/Parti Social Chrétien in Belgium', in ibid., 67-84, at 67.

36 Bruno Béthouart, 'Entry of the Catholics into the Republic: The Mouvement Républicain Populaire in France', in ibid., 85-IOO, at 86.

37 Schlemmer, Aufbruch, 9-10.

38 Alf Mintzel, Geschichte der CSU: Ein Überblick (Opladen: Westdeutscher Verlag, I977), 78-93.

39 R.E.M. Irving, The Christian Democratic Parties of Western Europe (London: George Allen \& Unwin, I979), II2.

40 For the integration of Catholics and Protestants into an interdenominational CDU, see Frank Bösch, Die Adenauer-CDU: Gründung, Aufstieg und Krise einer Erfolgspartei 1945-1969 (Stuttgart and Munich: Deutsche Verlags-Anstalt, 200I).

41 Schlemmer, Aufbruch, 90, 93. 
other hand, saw the party essentially as the successor to the BVP and favoured a federal solution for Germany that would privilege the autonomy of the regionstates. ${ }^{42}$ For the clerical conservatives, Bavaria was largely synonymous with Old Bavaria, a deeply rural and Catholic world in which the Counter-Reformation, the Thirty Years War and the Kulturkampf were the principal historical reference points. ${ }^{43}$ In the late I940s and early I950s, the balance of power within the CSU shifted towards the clerical conservatives, marginalising liberal, national-conservative and Protestant voices. ${ }^{44}$ Consequently, the CSU's claim to be an interdenominational party rang increasingly hollow. Indeed, in terms of membership and organisation the party seemed little more than an imitation of the BVP, thus alienating Franconian Protestants to the point of potential schism..$^{45}$

The CSU's claim to represent the Bavarian regionalist interest was also challenged by the emergence of the Bavarian Party (Bayernpartei or BP). First established in I946, the US occupation authorities refused the BP a licence to contest elections at the regional level until I948, thus shielding the CSU from a regionalist rival in its formative years. In the late I940s and early I950s, however, the BP made significant inroads into the CSU's electorate and its membership, above all in the Old Bavarian countryside. Like the CSU, the BP was also heir to the traditions of the BVP and, to a lesser extent, the BBB. And its particularism, characterised by Bavarian patriotism, extreme federalism and anti-Prussianism, appealed to many of the CSU's clerical conservatives. Importantly, there were even strong voices in the CSU urging closer co-operation between the two parties. ${ }^{46}$ Such demands hinted at the prospect of a new political constellation among Bavaria's regionalist forces. That this did not happen was primarily due to the opposition of Hans Ehard, then the Bavarian minister-president, and Franz Josef Strauss, the CSU general secretary at the time. Ehard feared that coalescing with the BP would discredit his strategy of constructive and moderate federalism, while Strauss disdained the BP's backward-looking parochialism, which he viewed as a hindrance to Bavaria's economic modernisation. ${ }^{47}$

The BP was not the only electoral competitor the CSU had to face in the late I940s and early I950s. As a consequence of the war and its aftermath, Bavaria became home to millions of refugees and expellees, coming mainly from the Sudetenland and Silesia. The US authorities had initially refused to license a refugees' party. As a consequence, in the I949 Bundestag elections, a significant number of refugees and expellees supported the populist Economic Reconstruction Association (Wirtschaftliche Aufbau-Vereinigung, WAV), propelling it to I4.4 per cent of the

42 Ibid., 90-I, 93.

43 Kuntz, 'Conservatives in Crisis', 69-70, I 56.

44 Schlemmer, Aufbruch, 365, 4I I.

45 Ibid., 365, 4I6, 4I 8, 437.

46 For the BP see Ilse Unger, Die Bayernpartei: Geschichte und Struktur 1945-1957 (Stuttgart: Deutsche Verlags-Anstalt, I979); Konstanze Wolf, CSU und Bayernpartei: Ein besonderes Konkurrenzverhältnis 1948-1960 (Cologne: Verlag Wissenschaft und Politik, I984).

47 Ian Farr and Graham Ford, 'Bavaria's "German Mission”: The CSU and the Politics of Regional Identity, I949-C.I962', in William Lancaster, Diana Newton and Natasha Vall, eds., An Agenda for Regional History (Newcastle: Northumbria University Press, 2007, forthcoming). 
vote. But by the time of the I950 Bavarian elections a specific refugees' party had come into being - the Union of Expellees and Dispossessed (Bund der Heimatvertriebenen und Entrechteten, BHE) - which managed to secure I2.3 per cent of the regional vote. ${ }^{48}$ At this point - in the early I950s - then, the combination of internal crisis and the fragmentation of the political landscape meant that the CSU seemed destined to share the fate of the BVP: to be a party from Bavaria rather than the party of Bavaria.

Yet by the early I960s the CSU had become the dominant political force in Bavaria; and a decade later it was the hegemonic 'official party' of Bavarian state and society. There is no simple explanation for this triumph, but a number of salient factors can be elucidated. The first of these is organisational. According to Mintzel, the 'turning point in the history of the CSU' was its expulsion from office in I954 by a four-party coalition composed of the social democrats, liberals, the BP and the BHE. This proved to be the catalyst for the overhaul of the party's internal structures, one consequence of which was that the clerical conservatives were gradually displaced by a younger generation of pragmatic politicians committed to an interdenominational, liberal-conservative and moderately federal party with a professional bureaucracy and a mass membership. ${ }^{49}$

The CSU's improved electoral performance during the I950s also stemmed from the economic context. By the second half of the decade West Germany had entered the era of the 'economic miracle'; and the Bavarian economy benefited particularly because the CSU drove a policy of regional economic modernisation, characterised by major infrastructural improvements and the siting of new technological industries, that transformed the region-state. ${ }^{50}$ The CSU was careful, however, not to abandon its more traditional supporters. Hence party leaders talked of Bavaria as an 'industrialagrarian state', which entailed economic support for farmers and small businesses, as well as a cultural policy that emphasised rural and small-town customs and traditions. ${ }^{51}$ 'Managed modernisation' therefore enabled Bavaria to avoid most of the social costs associated with nineteenth-century industrialisation. ${ }^{52}$ At the same time the concomitant erosion of traditional sociocultural milieux actually proved beneficial to the CSU, as the party was able to use its expanding organisational power to create an integral Bavarian social milieu of its own. ${ }^{53}$

Bavaria's rapidly growing economy also facilitated and benefited from the integration of the state's many refugees and expellees. ${ }^{54}$ But economic factors alone do not explain the CSU's ability increasingly to garner the support of Bavaria's newest inhabitants. Instead, the CSU eventually came to embrace an astute political course: acting as the principal advocate for the right of refugees and expellees to return to

48 The position of refugees and expellees is summarised in Karl-Ulrich Gelberg, 'Vom Kriegsende bis zum Ära Goppel (I945-I978)', in Schmid, Handbuch, 635-956, at 737-55.

49 Mintzel, Geschichte, 67-9; Schlemmer, Aufbruch, 482-4.

50 Milosch, Modernizing Bavaria; Gelberg, 'Vom Kriegsende', 840-3.

51 Weber, 'Föderalismus und Lobbyismus', 89-106; Farr and Ford, 'Bavaria's "German Mission”,

52 Mintzel, CSU-Hegemonie, 44.

53 Ibid., 54.

54 For the integration of expellees and refugees, see Gelberg, 'Vom Kriegsende', 747-50. 
their Heimat, while simultaneously actively promoting their integration into Bavarian state and society, their new Heimat. This policy was pursued most assiduously towards the largest expellee group, the Sudeten Germans. Hence in I954 the Bavarian state became their patron, and in I 962 the Sudeten Germans were designated as Bavaria's 'fourth tribe' alongside the Old Bavarians, Franconians and Swabians. ${ }^{55}$

These factors, then, allowed the CSU to assert itself as the dominant force on the Bavarian centre-right by the early I960s. Already by I957 the CSU was able to poll more than half the vote in that year's Bundestag elections, a triumph that owed much to the party's solid personal support for Konrad Adenauer, the federal chancellor. ${ }^{56}$ In regional parliamentary elections the CSU's advance to hegemony was more gradual: the party topped the poll in all seven electoral districts in 1958 , but this translated into only 45.6 per cent of the regional vote. By I970, however, the CSU secured more than half the overall vote, although it would be another four years before it won an absolute majority in each and every electoral district. ${ }^{57}$ For Mintzel, the CSU was therefore both agent and beneficiary of the homogenisation of Bavaria's political culture, which meant that for the first time a political party facilitated the process of intra-Bavarian integration alongside the state bureaucracy. ${ }^{58}$ What, though, of the CSU's identification with Bavaria as a place?

\section{The CSU and Bavaria's 'political character'}

The modern Bavarian state is essentially a product of late eighteenth- and early nineteenth-century power politics, so much so that it can be considered a 'French creation' ${ }^{59} \mathrm{CSU}$ leaders were, however, sensitive to any suggestion that Bavaria was an artificial entity. For example, Richard Jaeger, vice-chairman of the CSU regional group in the Bundestag, wrote that 'one cannot dismiss Bavaria as an arbitrary Napoleonic creation'. ${ }^{60}$ Instead, a teleological narrative of belonging was advanced to explain Bavaria's annexation of its new Swabian and Franconian territories, a narrative which explicitly rejected a simple linear continuity between Old Bavaria and modern Bavaria. Hans Ehard was therefore able to tell an audience in Nuremberg a predominantly Protestant city in central Franconia - that the modern Bavarian state 'was not the result of violence and war, but rather, as the time was ripe for the formation of new states, of the natural joining together of those that belong together' ${ }^{61}$ By choosing to 'forget' the violence and brutality that accompanied

55 Ibid., 753-4.

56 Mintzel, Geschichte, 377-80.

57 Mintzel, CSU-Hegemonie, 30, table 2.

58 Ibid., 45 .

59 Winfried Schulze, 'Bayern und die Französische Revolution: Machterweiterung und innere Reform', in Alois Schmid and Katharina Weigand, eds., Bayern mitten in Europa: Vom Frühmittelalter bis ins 20. Jahrhundert (Munich: C.H. Beck, 2005), 242-63, at 263.

60 'Deutscher und europäischer Föderalismus' (MS, I954), NL Jaeger P30, Archiv für Christlich-Soziale Politik (ACSP), Hanns-Seidel-Stiftung, Munich. This was the draft of an article published in Deutsches Monatsblatt (July I954), though the section from which the quotation is taken was removed before publication.

61 Bayerische Staatszeitung, I 5 July I950, I. 
Bavaria's enlargement, ${ }^{62}$ Ehard was able to portray this process as a 'marriage' between Old Bavaria and its new Franconian possessions. ${ }^{63}$

Ehard understood the Bavarian people in a similarly inclusive manner. Since the mid-nineteenth century, the Bavarian people (Staatsvolk) had been constructed as a union of four different 'tribes' (Stämme), namely the Old Bavarians, Franconians, Swabians and Palatines. ${ }^{64}$ But, as Hans Ehard argued, it was only together - as the Bavarian people - that they were able to give the state meaning. ${ }^{65}$ Such inclusivity was also applied to Bavaria's principal 'foundation myth': the claim in the preamble to the I946 state constitution to 'the more than one-thousand year history of the Bavarian people'.

This phrase originally alluded to the Bajuwaren, the supposed antecedents of the Old Bavarians, whose existence was first recorded several decades after the withdrawal of the Romans from southern Germany. ${ }^{66}$ In particular, it was generally understood to refer to the establishment of the stem duchy of Bavaria under Garibald I in the sixth century. ${ }^{67}$ Ulrike Stoll is representative of most historical opinion when she writes of the preamble, 'This reference was not historically accurate as it equated the history of Bavaria with the history of Old Bavaria'. ${ }^{68}$ However, the term 'Bavarian people' was suitably ambiguous to allow for a more expansive reading. Against the backdrop of postwar intra-Bavarian tensions, Ernst Deuerlein - at the time Ehard's principal speech writer and later an academic historian - claimed that 'when the new Bavarian constitution refers to the one-thousand year history of Bavaria, it calls to mind the four [sub-]regions of Old Bavaria, Swabia, Franconia and the Palatinate'. ${ }^{69}$ And articles in the Bayern-Kurier profiling the region's cities provided historical substance for this view, for Regensburg (Old Bavaria), Augsburg, Kempten (both Swabia) and Rothenburg ob der Tauber (Franconia) were each more than a thousand years old. ${ }^{70}$

Modern Bavaria, as conceptualised by CSU politicians, was not, then, to be confused with Old Bavaria. It was, instead, to be understood as a synthesis of the different tribes and traditions that had come together under the auspices

62 Rudolf Endres, 'Der "Fränkische Separatismus”: Franken und Bayern im I9. und 20. Jahrhundert', Mitteilungen des Vereins für Geschichte der Stadt Nürnberg, 67 (I980), I 57-83, at I 57, I 59-6I.

63 Bayerische Staatszeitung, I 5 July I950, I.

64 For the concept of 'Stämme', see Karl Bosl, 'Was sind Stämme und welche Rolle spielen sie im modernen bayerischen Staat?', in Rainer A. Roth, ed., Freistaat Bayern: Die politische Wirklichkeit eines Landes der Bundesrepublik, 4th edn (Munich: Bayerische Landeszentrale für politische Bildungsarbeit, I986), I27-37. The Bavarian Palatinate was in the French occupation zone and was therefore incorporated into the new region-state of Rhineland-Palatinate in I946. However, the Bavarian government continued to agitate for its return until I956. See Karl-Ulrich Gelberg, 'Die bayerische Pfalzpolitik I945-I956 mit einem Quellenanhang', Zeitschrift für bayerische Landesgeschichte, 58, 2 (I995), 637-72.

65 Hans Ehard, 'Franken in Bayern', in Hans Ehard, Bayerische Politik: Ansprachen und Reden des bayerischen Ministerpräsidenten (Munich: Richard Pflaum Verlag, I952), I6I-7I, at I64.

${ }^{66}$ Karl Bosl, 'Die historische Staatlichkeit der Bayerischen Lande', Zeitschrift für bayerische Landesgeschichte, 25, I (I962), 3-I9, at I8-I9. For the origins of the Bajuwaren, see Hartmann, Bayerns Weg, 44-8.

67 For the stem duchy of Bavaria, see ibid., 49-52.

68 Stoll, 'Bayern', 23. See also Kuntz, 'Conservatives in Crisis', I 56.

69 Bayerische Staatszeitung, I 5 July I950, 5-6, at 6.

70 Bayern-Kurier, 5 July I952, 3; I 3 June I953, 3; 3 June I950, 8; I6 Jan. I954, 3. 
of the Wittelsbachs to form the modern Bavarian state in the early nineteenth century. In this respect, Bavaria's historical diversity could be constructed as the common heritage of all modern Bavarians. As such, for Ehard and Seidel Bavaria's 'political character', epitomised by the commitment to federalism, stemmed from the synthesis of two political traditions: the 'state consciousness' of Old Bavaria and the 'Reich consciousness' of Franconia and Swabia, the 'Reich' in this case being the Holy Roman Empire. ${ }^{71}$ Hence Bavaria's 'historic statehood' was rooted in Old Bavaria's 'state tradition', a particular staple of Catholic regionalists; while Bavaria's commitment to Germany was exemplified by the former imperial territories of the modern state's Franconian and Swabian sub-regions, a notion likely to resonate with Protestants of all political persuasions but especially liberals and conservative nationalists. The articulation of this 'state tradition' was particularly bound up with monarchy. The genesis of the Bavarian state was therefore closely identified with Regensburg, for 'with the expulsion of the Romans [it] became the ducal seat of the Agilolfings', ${ }^{72}$ the dynasty to which Garibald I belonged. This allowed Seidel to claim that the Old Bavarians were the first German 'tribe' to possess a capital, thus emphasising the pre-eminence of Bavarian statehood among West Germany's regionstates. ${ }^{73}$ But it was with the House of Wittelsbach, which reigned between I 80 and I9I 8, that Bavaria's subsequent history was most closely associated. Consequently, historical sites connected with the Wittelsbachs functioned as modern reaffirmations of Bavarian statehood. In particular, given the three partitions of Bavaria in the thirteenth and fourteenth centuries, four cities had, at one time or another, been ducal seats: Straubing, Ingolstadt, Landshut and Munich. ${ }^{74}$

Apart from Munich, the most important of these cities was Landshut. Commemorating its 750th anniversary in 1954, the Bayern-Kurier noted that Landshut's origins were an expression of political will. Landshut was already a settlement at the foot of an old watchtower, and Duke Ludwig I elevated it to a city in I204. Subsequently, 'the new city of Landshut was deliberately developed by Ludwig and his son, Duke Otto II, into the capital of the Duchy of Bavaria'..$^{75}$ Landshut's 'golden era' was during the fourteenth and fifteenth centuries; indeed, 'during the entire fifteenth century the Wittelsbach Dukes of Bavaria-Landshut belonged to the most influential princely houses of Europe', with all three dukes earning the epithet 'the Rich'. ${ }^{76}$ The most ostentatious example of this wealth was the wedding that Ludwig IX held for his son Georg and Hedwig, the daughter of Casimir IV, the king of Poland, in I475. The historical re-enactment of this marriage, the socalled 'Landshut Royal Wedding' - first performed in I903 - was and is, therefore, a

71 Ehard, 'Franken in Bayern', I65; 'Die Aufgabe Bayerns', MS, n.d. [1955?]), NL Seidel 8, ACSP; Bayerische Verwaltungsblätter, July I958, I93, NL Seidel I4, ACSP.

72 Bayern-Kurier, 5 July I952, 3.

73 Hanns Seidel, 'Die Haupt- und Residenzstadt München', in Hanns Seidel, Zeitprobleme: Gesammelte Aufsätze und Vorträge (Aschaffenburg: Paul Pattloch Verlag, I960), 207-I3, at 208.

74 For the partitions of Bavaria, see Hartmann, Bayerns Weg, IOI-22. Bavaria was reunified in I 505.

75 Bayern-Kurier, 3 July I954, 3 (emphasis in original).

76 Ibid. 
heritage event invested with regional political meaning as a vital modern reaffirmation of Bavarian statehood.

It could be argued that for the Bayern-Kurier, the significance of the re-enactment did not lie solely with Georg's marriage to Hedwig, but also with the message it conveyed about the Bavarian 'state tradition'. At one level, the 'Royal Wedding' was an expression of the Wittelsbachs' power and influence within the Holy Roman Empire, evidenced by a guest list headed by Kaiser Friedrich III. More importantly, the re-enactment signalled the symbiotic relationship between monarchy and people, exemplified by Ludwig's generosity in paying for the local townsfolk to celebrate the occasion. ${ }^{77}$ This symbolism was further reinforced by the fact that both the Bavarian minister-president and the head of the House of Wittelsbach - Crown Prince Rupprecht until his death in I957, then Duke Albrecht - were the joint patrons of the festival. ${ }^{78}$ Thus, despite Bavaria's having had a republican form of government since I9 I 8, Rupprecht and Albrecht continued to assume the monarchy's role as the 'dignified part' of the constitution, ${ }^{79}$ which meant that they personified the continuity of Bavarian statehood.

As the Landshut 'Royal Wedding' intimated, this state tradition did not exist independently of Germany. Rather, as Seidel put it, there was an 'age-old symbiosis between Bavaria's conception of the state (Staatsdenken) and the concept of the Reich (Reichsdenken)'. This symbiosis was strengthened, he claimed, with the creation of modern Bavaria, 'for the Reich, which at the same time was Germany, was even more at home in those Franconian and Swabian imperial (reichsständisch) territories than in the Wittelsbach territorial state' ${ }^{80}$ The 'Reich consciousness' of these territories was exemplified most clearly by the former free imperial cities (Reichsstädte), such as Nuremberg, Rothenburg and Dinkelsbühl in Franconia, and Augsburg, Kempten and Kaufbeuren in Swabia; they were 'city-states' that were subject to the direct authority of the kaiser rather than a territorial prince. Of these, the most important was Nuremberg. As Rudolf Schieffer has recently written, 'Until i 806 Nuremberg was not a site of Bavarian history, but rather of Reich history, of its kaisers and kings'. ${ }^{81}$

But this history also belonged to Bavaria's common heritage and was celebrated as such. This was apparent during Nuremberg's 9ooth anniversary celebrations in

77 Ibid., Io June I950, 6; I 3 June I953, 9; 7 July I956, 3; 4 July I959, 3; 23 June I962, 8, Io. See also Erich Stahleder and Stefan Härtl, Schlag nach: Die 'Landshuter Hochzeit 1475'. Der Verein 'Die Föderer' e.V., Daten+Fakten, Zugfolge, 4th edn (Landshut: Selbstverlag des Vereins 'Die Föderer' e.V., 2005), esp. I $2-15$.

78 Bayerische Staatszeitung, I4 July I953, 7; Bayern-Kurier, 23 June I962, 8.

79 Jürgen Gebhardt, 'Bayern, Deutschlands eigenwilliger Freistaat - Historisch-gesellschaftliche Aspekte der politischen Kultur in Bayern', in Roth, ed., Freistaat Bayern, 83-I04, at 88.

80 Bayerische Verwaltungsblätter, July I958, I93, NL Seidel I4, ACSP.

81 Rudolf Schieffer, 'Nürnberg: Die Kaiserburg als Herrschaftszentrum der Salier und Staufer', in Alois Schmid and Katharina Weigand, eds., Schauplätze der Geschichte in Bayern (Munich: C.H. Beck, 2003), 90-I03, at 90. 
I950. Here the historical emphasis was very much on Nuremberg as a German city, ${ }^{82}$ with Ehard proclaiming that '900 years of Nuremberg means 900 years of German history'. ${ }^{83}$ As Clemens Wachter has shown, one of the three principal focal points of the celebrations was 'Nuremberg and the medieval empire', with the organisers keen to stress the city's loyalty to kaiser and empire. ${ }^{84}$ And this was a theme taken up by the Bayern-Kurier. Despite Nuremberg's prosperity in the fourteenth and fifteenth centuries, this was a city, the paper argued, that

did not forget its association with the kaiser and the empire. Karl IV's Golden Bull of 1356 thus honoured Nuremberg by determining that each kaiser should hold his first imperial diet in Nuremberg. Not many decades later, the imperial regalia, the most precious symbols of medieval glory, came to Nuremberg. So Nuremberg became the secret capital of the medieval empire. ${ }^{85}$

This claim certainly pandered to local sensibilities, but it had greater political resonance. In identifying Nuremberg as the 'secret capital' of the Holy Roman Empire during the medieval period, the Bayern-Kurier was not only anchoring Bavaria's political heritage firmly within Germany, it was locating this heritage at the heart of German affairs. Nuremberg's loyalty to the empire in the past, therefore, evoked modern Bavaria's commitment to Germany in the present.

As with Bavarian statehood, historical re-enactment also played a role in continuing to sustain the idea of Reich consciousness, most notably in Kaufbeuren's 'Tänzelfest', reputedly the oldest children's festival in Germany. The Tänzelfest had its origins in a visit to the city by Kaiser Maximilian I in I497, and 'his' ceremonial entry into the city played an important role in the festival. But its symbolic highpoint was the oath of allegiance that the burghers swore to the Kaiser in front of the town hall, a clear reminder that Kaufbeuren was once a city of the Reich. ${ }^{86}$ Taken together, the festival's various elements were, according to the Bayern-Kurier, 'a piece of Kaufbeuren's past, a piece of Swabian, Bavarian and German history', ${ }^{87}$ thus acknowledging the multiple interlocking identities located within Bavaria's common heritage.

It was Munich, though, that stood as the physical, urban embodiment of the modern Bavarian state. Founded in I I58, Munich's subsequent development as a centre of political power was integrally linked to the Wittelsbach monarchy. And, like the dynasty, Munich was ultimately constrained by Old Bavaria. As Seidel told an audience during the city's 8ooth anniversary celebrations in 1958, Munich's opportunities to shape political events during the medieval and early modern periods were limited by the fact that it was the capital of a relatively small territorial state. With the establishment of the modern Bavarian state, however, Munich's political importance was enhanced. But, for Seidel, the political Munich that now emerged

82 Clemens Wachter, Kultur in Nürnberg 1945-1950: Kulturpolitik, kulturelles Leben und Bild der Stadt zwischen dem Ende der NS-Diktatur und der Prosperität der fünfziger Jahre (Nuremberg: Stadtarchiv Nürnberg, I999), 364 .

83 Bayerische Staatszeitung, I 5 July I950, I.

84 Wachter, Kultur in Nürnberg, 363.

85 Bayern-Kurier, I 5 July I950, 6.

86 Ibid., 22 July I96I, 6; I4 July I962, 6.

87 Ibid., 22 July I96I, 6. 
was no longer an Old Bavarian city as such: 'The city became a true reflection of Bavaria's new population structure, it acted like a great melting pot, it supported the growing together of the Bavarian population and so contributed fundamentally to the creation of a new Bavarian state tradition, to the shaping of the Bavarian people [Staatsvolk] and a state consciousness'. ${ }^{88}$

\section{The CSU and Bavaria's cultural heritage}

The construction of the CSU's integral Bavarian identity was not just a question of 'political heritage'. Bavaria was understood to be a 'cultural state'. Consequently, Ehard emphasised an inclusive understanding of the region's cultural heritage, claiming that Bavaria had developed a 'common culture' and a 'common cultural consciousness' during the course of the nineteenth century as a synthesis of the region's diverse cultural traditions. ${ }^{89}$ And Hanns Seidel made a similar point when addressing the Junge Union - the youth wing of the CDU/CSU - in Straubing in I958 when he noted that ' $[\mathrm{t}]$ he particular cultural wealth of Bavaria is based on the harmony of [the] three tribes'. 'Here', he went on to add, 'the colourful splendour of the Old Bavarian and Upper Swabian Baroque abbeys has as much place as the Protestant burgher cultures of the former imperial cities of Franconia and Swabia.' ${ }^{90}$

Bavaria's urban cultural heritage was located primarily, although by no means exclusively, in the former imperial cities - that is, in the historic urban landscape, epitomised by premodern, usually medieval, buildings: cathedrals, churches, patrician houses, towers and walls. These were commodified townscapes, to be consumed as a common Bavarian heritage, even after sometimes extensive wartime damage, through various publications, such as the Bayern-Kurier, or experienced more directly by readers either as delegates to CSU party gatherings or simply as tourists. ${ }^{91}$ The emphasis on the premodern was by no means peculiar. The popularity of the Middle Ages was a European phenomenon; ${ }^{92}$ and it is within this context that the 'beautiful old town' became a symbol of German cultural identity in the nineteenth century. ${ }^{93}$ Here, within the built environment of cities such as Rothenburg, Augsburg and Regensburg, Bavaria could boast of a rich architectural heritage, a heritage that placed modern Bavaria at the heart of German and European cultural developments. ${ }^{94}$

Such historic urban landscapes were emblematic of the symbiotic relationship between the regional and the national: tangible evidence that Bavaria's past was

88 Seidel, 'Die Haupt- und Residenzstadt München', 2 I I-I 2.

89 Ehard, 'Franken in Bayern', I67.

90 'Freiheit, Heimat, Vaterland. Ansprache des Ministerpräsidenten Dr. H. Seidel auf der Landesversammlung der Jungen Union in Straubing am 28.9.1958' (MS), NL Seidel I5, ACSP.

91 On the consumption of the historic urban landscape see Rudy Koshar, 'Altar, Stage and City: Historic Preservation and Urban Meaning in Nazi Germany', History and Memory, 3, I (I99I), 30-59, esp. $35-6,47$.

92 Keith D. Lilley, Urban Life in the Middle Ages 1000-1450 (Basingstoke: Palgrave, 2002), I 8.

93 Jürgen Paul, cited in Joshua Hagen, 'Rebuilding the Middle Ages after the Second World War: The Cultural Politics of Reconstruction in Rothenburg ob der Tauber', Journal of Historical Geography, 3 I, I (2005), 94-II2, at 95 .

94 Bayern-Kurier, 5 July I952, 3; I3 June I953, 3; I6 Jan. I954, 3. 
inseparable from that of Germany. As the 'ancestral' capital of the Old Bavarians, Regensburg was a case in point, with the Bayern-Kurier informing its readers that 'for every visitor to Regensburg a stay inside its walls becomes a trip through the centuries, through the history of Bavaria and Germany'. ${ }^{95}$ Some of these 'medieval' townscapes, such as Dinkelsbühl's, were even elevated to the status of national icon. ${ }^{96}$ But it was Munich, as the regional capital, that occupied a particularly important place in this schema. Its nineteenth-century neoclassical transformation earned it the epithet 'Athens on the Isar', a city, paraphrasing Ludwig I, 'that had to be seen by anyone who wanted to boast of having seen Germany'. ${ }^{97}$ As such, Munich's urban heritage spoke of Bavaria's centrality to and cultural pre-eminence in the (West) German state.

Bavaria's cultural heritage was not just a matter of the historic built environment, but also encompassed cultural figures - artists, sculptors, musicians, writers and the like - and their works. Towns and cities were particularly eager to promote their connections with cultural producers of regional and, above all, national standing usually as the place of birth and/or residence - in order to foster local pride and identity. But in the pages of the Bayern-Kurier the local was constitutive of the regional and, in turn, of the region's contribution to the national. Once again, however, Bavaria's cultural heritage drew heavily on its former imperial cities, above all Augsburg and Nuremberg. Pointing to painters such as Hans Holbein the Elder, Hans Holbein the Younger and Hans Burgkmair, as well as the sculptor Gregor Erhart, Augsburg claimed to be the crystallisation point of German art in the Middle Ages. ${ }^{98}$ Nuremberg not only rivalled, but in many respects surpassed, Augsburg as a cultural centre in the late fifteenth and early sixteenth centuries. This was Nuremberg's golden age, a period in which the city embodied the 'humanistic spirit' in art and science, epitomised by such nationally important figures as Willibald Pirkheimer (humanist), Veit Stoss (sculptor), Adam Kraft (sculptor), Peter Vischer the Elder (brazier), Hans Sachs (poet and cobbler), Peter Henlein (clockmaker) and, most famously of all, Albrecht Dürer. ${ }^{99}$ These men and their works were therefore Bavarians' common heritage, tangible evidence not only of Bavaria's cultural wealth, but of Bavaria's centrality to the culture of both Germany and Europe.

\section{The CSU and Bavaria's Christian identity}

The CSU's identification with Bavaria, then, was very much rooted in 'political' and 'cultural' conceptions of the state. But there was also a third dimension to the party's regional identity: it also attached a deeper 'meaning' to Bavaria as a Christian state. In particular, it forged an identity around a regional 'sense of mission'

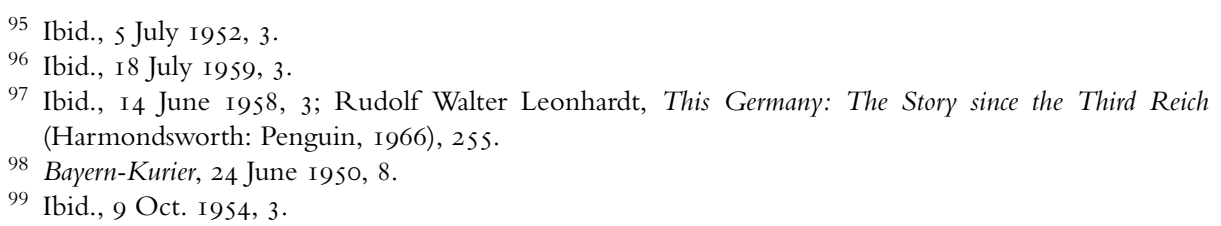


(Sendungsbewußtsein), which Mintzel has conceptualised as the 'Christian bulwark of Bavaria'. ${ }^{100}$ This accorded the region-state a privileged position both as the impetus for the Christian Occident's (das christliche Abendland) spiritual renewal and as its defender against godless communism. ${ }^{101}$ The 'Christian Occident' was a staple of West German and Austrian Christian Democrats in this period. A somewhat diffuse notion, its appeal lay in a vision of Europe rooted in medieval Christendom and a concomitant rejection of materialism and secularism. ${ }^{102}$ Since it was primarily a Catholic concept, the Church was at the forefront of organising commemorations during the late I940s and early I950s to invest the 'Occident' with historical legitimation. ${ }^{103}$ Yet the idea of the 'Christian Occident' also had its Protestant adherents. ${ }^{104}$ Moreover, with the development of the Cold War, its practical political expression rested on a virulent anti-communism, something which resonated with most German Protestants, although some had doubts about Western integration and remilitarisation. ${ }^{105}$ While it is certainly the case that in the early I950s the CSU was increasingly Catholic, much to the resentment, disillusionment and disgruntlement of its Protestant members, ${ }^{106}$ there is nevertheless evidence to suggest that an attempt was made to invest Bavaria's 'mission' with interdenominational resonance.

For example, in I952 the Catholic Bishopric of Würzburg celebrated the I,200th anniversary of the interment of the relics of St Kilian, the patron saint of both the episcopate and the city. Born in Ireland in about 640, Kilian was martyred in Würzburg, along with his two Irish companions, St Totnan and St Coloman, in 689. Together, these three 'missionaries' were credited with Christianising Franconia, with Kilian subsequently earning the epithet 'Apostle of Franconia'. ${ }^{107}$ In his speech, Hans Ehard drew on this Franconian Christian heritage as a source for Bavaria's 'sense of mission', identifying the 'Franconian apostles' with the creation of Christian Europe and consequently the 'Franconian-Bavarian Bishopric of Würzburg' with a 'European ethos'. ${ }^{108}$ It was this Europe that was threatened by 'the shadow of a materialistic world', an allusion to the forces of secularism, above all the communist east. Repulsing this threat, he argued, was 'only possible through a strengthening

100 Mintzel, Geschichte, 272ff.; also Kuntz, 'Conservatives in Crisis', I62-8.

101 See, e.g., Staatspolitische Umschau der 'Bayerischen Einigung' e.V., July-Aug. I959, NL Besold 6, ACSP.

102 Axel Schildt, Zwischen Abendland und Amerika: Studien zur westdeutschen Ideenlandschaft der 5oer Jahre (Munich: Oldenbourg, I999), esp. 2I-38; Ronald J. Granieri, The Ambivalent Alliance: Konrad Adenauer, the CDU/CSU, and the West, 1949-1966 (New York and Oxford: Berghahn, 2003), esp. I3-I 8; Dieter A. Binder, "'Rescuing the Christian Occident" and "Europe in Us": The People's Party in Austria', in Gehler and Kaiser, Christian Democracy, I39-54.

103 Matthias Pape, 'Lechfeldschlacht und NATO-Beitritt: Das Augsburger "Ulrichsjahr" I955 als Ausdruck der christlich-abendländischen Europaidee in der Ära Adenauer', Zeitschrift des Historischen Vereins für Schwaben, 94 (200I), 269-308, at 27I.

104 Schildt, Abendland, 32-3, 36.

105 Ibid., 34-5; Bösch, Die Adenauer-CDU, 40-I; Mintzel, Geschichte, $284 \mathrm{ff}$.

106 Schlemmer, Aufbruch, 4I2-I7.

107 Although it is far from certain that Kilian was active as a missionary. See Knut Görich, 'Irland. Bekehren und belehren: irische Mönche in Bayern', in Schmid and Weigand, Bayern mitten in Europa, $45-58$, at 5I-2.

108 Medieval Irish monks were frequently identified as the harbingers of European integration after the war. See Görich, 'Irland', 45 . 
of faith', inspiration for which was provided by the founders of the city and the bishopric. ${ }^{109}$ Yet this speech cannot be understood simply in Catholic terms. For although Ehard has been criticised for paying only lip service to Protestant concerns within the $\mathrm{CSU},{ }^{110}$ he nevertheless had a denominationally inclusive understanding of the Bavarian state. Hence earlier in his address Ehard pointed out that the 'Franconian Circle' of the Holy Roman Empire had consisted of both Catholic and Protestant territories: the bishoprics of Würzburg, Bamberg and Eichstätt on the one hand and the principalities of Ansbach and Bayreuth and the free imperial city of Nuremberg on the other. ${ }^{111}$ Moreover, through a process of encounter, Franconia had developed a religious consciousness that 'tried more and more to work out what the Christian faiths had in common', ${ }^{112}$ a clear allusion to the city's irenical tradition. ${ }^{113}$ It was these traditions of coexistence, he argued, that were indispensable to Bavaria after I 8 I 5. Within this broader context, his invocation to a 'strengthening of faith' can be understood as a Christian rather than a Catholic message. ${ }^{114}$

One Bavarian city, however, was synonymous with both the defence of the Occident and denominational reconciliation: Augsburg. The former was symbolised by St Ulrich and the battle of Lechfeld in 955, the latter by the Peace of Augsburg in I 555 . In 955 the nomadic Magyars swept across Bavaria and Swabia, before eventually laying siege to Augsburg. Here Bishop Ulrich led the defence of the city, allowing time for King Otto I to muster his army and move south, where he engaged and defeated the Magyars on the Lechfeld. ${ }^{115}$ Even before the millennium of the battle, the Lechfeld had become a touchstone for the defence and victory of the Christian Occident against the threat from the communist east. ${ }^{116}$ But as Matthias Pape has recently shown, attempts to exploit the Lechfeld and St Ulrich reached their apogee in I955, in millennium celebrations choreographed by the conservative Catholic Bishop of Augsburg, Joseph Freundorfer. ${ }^{117}$ Yet while the dominant tone of the Lechfeld commemorations was Catholic, they were not exclusively so. After all, 60,000 Catholics and Protestants packed the city's Rosenau stadium to hear speeches by, among others, the new federal foreign minister, Heinrich von Brentano (CDU) and the federal president, Theodor Heuss of the Free Democratic Party (FDP). ${ }^{118}$ Brentano used the occasion to engage in anti-communist rhetoric, emphasising the

109 Ehard, 'Franken in Bayern', I70-I.

110 Schlemmer, Aufbruch, 4I7. Cf. Gelberg, Hans Ehard, 463-4.

111 Ehard, 'Franken in Bayern', I65.

112 Ibid., I66.

113 Werner Blessing, 'Religionen in der Region', in Hermann Glaser and Rainer Lindenmann, eds., Typisch deutsch...! Typisch fränkisch...! Lebensweisen, Haltungen, Klischees (Cadolzburg: Ars Vivendi Verlag, 2003), 98-I I I, at I05; Dieter Schäfer, Geschichte Würzburgs (Munich: C.H. Beck, 2003), I I9.

114 It is worth noting, however, that while the report in the Bayern-Kurier stressed the Franconian nature of the commemoration, it was also more Catholic in tone. See Bayern-Kurier, I9 July I952, 3.

115 Manfred Weitlauff, 'Das Lechfeld: Die Entscheidungsschlacht gegen die Ungarn 955', in Schmid and Weigand, Schauplätze, 55-74, at 68-70.

116 'Augsburg' (MS, July I95I), NL Martin 35, ACSP; Bayern-Kurier, 24 Jan. I950, 8; ibid., I3 June I953, 3; Pape, 'Lechfeldschlacht', 295.

117 Pape, 'Lechfeldschlacht', esp. 283-93.

118 Schildt, Abendland, 38. 
contemporary eastern threat to the Christian Occident, a line that was consistent with that of the CSU. ${ }^{119}$ Heuss, on the other hand, used his speech to emphasise another commemoration, that of the Peace of Augsburg. ${ }^{120}$ This too was consistent with the CSU's identity.

The symbolic importance of the Peace of Augsburg for an interdenominational Christian party is unmistakeable, for it had recognised the parity of Lutheranism with Catholicism in the Holy Roman Empire. ${ }^{121}$ Therefore, even before its quatercentenary the Peace was being exploited for the CSU's identity formation. For example, in the week before Augsburg hosted the I953 CSU party conference, the Bayern-Kurier noted that the Peace 'was of the greatest significance for peace and toleration between the confessions'. The headline writer was even more explicit: 'City of the Religious Peace - City of the UNION' the paper proclaimed, thus eliding a celebratory reading of the historical event with the political identity of the party. ${ }^{122}$ When the Junge Union (JU) held its annual conference in Augsburg two years later, Franz Sackmann, the regional chairman of the JU in Bavaria, and Hans Drachsler, the chairman of the JU in Lower Bavaria and editor of the Bayern-Kurier, unashamedly instrumentalised both the battle of Lechfeld and the Peace of Augsburg to further the CSU's virulent anti-communism and to invoke Bavaria's Christian heritage in shaping the direction of West German Christian Democracy. These two historical events were, they claimed, 'the correct guide for the future of the new generation of Union politicians'. Yet the message was also unambiguously interdenominational. Hence the Lechfeld was 'the expression of the Christian-Occidental willingness to repulse the danger of atheism and servitude that threatens from the east', while the Peace of Augsburg symbolised 'for us the solemn duty to strengthen the defences against the eastern threat with the sure weapon of the co-operation and unity of both confessions'. ${ }^{123}$

\section{Conclusion}

The CSU's hegemonic domination of Bavarian politics since the I970s has led to the elision of party and state: the CSU is the 'official party' of Bavarian state and society. In the late I940s and early I950s, by contrast, the 'meaning' of this identity was a contested terrain within the CSU, so much so that a realignment of the party political landscape on the centre right was by no means out of the question. As this article has shown, even before the 'turning point' of the mid-I950s, the CSU was in the process of constructing an integral Bavarian identity: articulating an inclusive vision of the region-state by exploiting the past as a 'political resource', presenting modern Bavaria's diverse histories as a common heritage. This heritage was given tangible

119 Ibid.; Bayern-Kurier, 2 I May I955, 3.

120 Schildt, Abendland, 38 ; Pape, 'Lechfeldschlacht', 300.

121 Manfred Heim, 'Augsburg: Der Religionsfriede von I555', in Schmid and Weigand, Schauplätze, 205-2I5.

122 Bayern-Kurier, I 3 June I953, 3.

123 Ibid., 2 I May I955, 3. 
meaning through a local sense of place, fostering local pride, certainly, but more importantly, configuring the uniqueness of the local as representative of the 'tribal', the regional and, significantly, the national. As examples elsewhere demonstrate, the instrumentalisation of the past is fundamental to the identity formation of ethnoregionalist parties. ${ }^{124}$ But whereas ethno-regionalist parties typically use the past to assert their distinctiveness from the national state in order to legitimise demands for cultural protection, autonomy, federalisation or separation, ${ }^{125}$ the CSU asserted its regionalism as constitutive of the nation. The CSU was thus able to accommodate the 'white-blue' patriotism of Catholic Old Bavaria, while avoiding the particularist excesses of the BVP, the BP and even its own clerical-conservative wing. At the same time, by locating Bavaria's 'imagined past' firmly within a German historical context, the CSU committed Bavaria's 'imagined future'126 to the German nation and the fledgling West German national state, something which spoke to liberal and national-conservative opinion, above all in Protestant Franconia. The construction of such an integral Bavarian identity, therefore, provided legitimation for the CSU's claim to be an interdenominational party that was able to represent both the regionalist and national interest. The extent to which this identity came to have wider resonance both within Bavaria and beyond is surely worthy of further investigation.

124 Josep R. Llobera, 'The Role of Commemorations in (Ethno)Nation-Building. The Case of Catalonia', in Clare Mar-Molinero and Angel Smith, eds., Nationalism and the Nation in the Iberian Peninsula: Competing and Conflicting Identities (Oxford and Washington, DC: Berg, I996), I9I-206; William Brierley and Luca Giacometti, 'Italian National Identity and the Failure of Regionalism', in Brian Jenkins and Spyros A. Sofos, eds., Nation and Identity in Contemporary Europe (London and New York: Routledge, I996), I72-97, at I 85; Marco Tarchi, 'The Lega Nord', in De Winter and Türsan, Regionalist Parties, I43-57, at I45.

125 Lieven De Winter, 'Conclusion. A comparative analysis of the electoral, office and policy success of ethnoregionalist parties', in De Winter and Türsan, Regionalist Parties, 204-47, at 205-7.

126 See more generally Ashworth and Graham, 'Senses of Place', 4. 